\title{
КОРПОРАТИВНІ ПРАВОВІДНОСИН ТА ПОДАТКОВІ РОЗРИВИ: ТЕОРЕТИЧНИЙ ПІДХІД
}

\author{
Славкова Олена Павлівна \\ доктор економічних наук, профресор \\ Сумський національний аграрний університет (м.Суми, Україна) \\ ORCID: 0000-0002-1864-0810 \\ olena.slavkova.snau@gmail.com \\ Гордієнко Микола Іванович \\ кандидат економічних наук, професор \\ Сумський національний аграрний університет (м.Суми, Україна) \\ ORCID: 0000-0003-0686-9797 \\ migsumy1963@ukr.net
}

\begin{abstract}
У статті проаналізовано міжнародну практику використання оцінки податкових розривів, зокрема в Австралії, Канаді, Сполученому Королівстві, Сполучених Штатах Америки, Швеції та інших. З'ясовано, що цей показник розглядається як похідна від рівня податкової культури національної економіки, підприємств, організацій та громадян країни та характеризується невисоким рівнем податкового розриву.

Установлено, що основним базовим компонентом визначення розміру податкового розриву у розвинених державах загальне декларування доходів та звітування. Визначено, що корпоративні права є об'єктом оподаткування. Проведено аналіз законодавства України та зроблено висновок, що діюче законодавство України не відповідає сучасним вимогам та законодавству ЄС. У статті 15 Договору про Європейський Союз закріплено, що важливою умовою для зміцнення економічних зв'язків між Україною та Співтовариством є зближення існуючого та майбутнього законодавства України з законодавством Співтовариства. Україна вживе заходів для забезпечення того, щоб їі законодавство поступово було приведене у відповідність до законодавства Співтовариства». До такого законодавства належить і законодавство яким врегульовуються питання визнання, оцінки, обліку і оподаткування корпоративних прав.

Зроблено висновок про те, що на державному рівні необхідно впроваджувати дієву систему звітування та перевірки для зменшення податкових розривів в секторі корпоративних прав.
\end{abstract}

Ключові слова: управління, оподаткування, податковий розрив, корпоративні права, корпоративні правовідносини.

DOI: https://doi.org/10.32845/bsnau.2019.4.1

Постановка проблеми у загальному вигляді. В багатьох розвинених країнах з метою оцінки ефективності функціонування податкової системи використовується такий показник як податковий розрив.

Аналізуючи динаміку цього показника можна визначити ефрективність процесів адміністрування податків та вона слугує важливим аналітичним інструментом підтримки процесів прийняття рішень в напрямку державної податкової політики.

Цей показник розглядається як похідна від рівня податкової культури підприємств, організацій та громадян країни та характеризується невисоким рівнем податкового розриву.

Аналіз останніх досліджень і публікацій.Серед основних дослідників податкових розривів можна виділити: $\mathrm{N}$. Warren, J. McManus (Warren N., McManus J., 2007), S. Hamilton (Hamilton S., 2015), N. Gemmell, J. Hasseldine (Gemmell N., Hasseldine J., 2012), М. М. Фільо (Фільо М. М., 2014), А. М.Вдовиченко, А. І. Зубрицький (Вдовиченко А. М., Зубрицький А. І., 2013), К. І. Швабій, Л. А. Задорожня (Швабій, К. І., Задорожня, Л. А., 2018) та інші.

Аналізуючи дослідження даної проблеми у вітчизняній науці можемо сказати, що ця категорія недостатньо досліджена в вітчизняній літературі та заслуговує на увагу.

Формування цілей статті.Метою даної статті $€$ аналіз підходів до визначення поняття податкових розривів та застосування даного методу в сфері корпоративного управління з метою детінізації економіки.

Методи дослідження. В ході проведення дослі-

дження були використані наступні методи, а саме: систематизації та узагальнення - при аналізі нормативних документів та теоретичних джерел; діалектичний - при формуванні визначення податкові розриви та корпоративні правовідносини, абстрактно-логічний метод - для визначення пріоритетних напрямів державного регулювання та розробки пропозицій 3 детінізації економіки на основі обрахунку податкових розривів.

Результати дослідження. В нашій країні поняття податкових розривів новітнє та ще недостатньо досліджене. За своєю природою податковий розрив - це інтегральний показник. PR, який дорівнює різниці між податковими надходженнями, отриманими від всіх сплачених податківвідповідно до чинного законодавства своєчасно та в повному обсязі, а також фрактично отримані податками (Швабій, К. І., Задорожня, Л. А., 2018). Розрахунок даного показника проводиться по окремому податку або за всіма податками одразу.

Аналіз публікацій показує, що більшість дослідників даної категорії відносяться до зарубіжних. Так С. Хамільтон (Hamilton S., 2015) вважає, що такий показник $є$ інформативним у контексті чіткості податкової політики та їі сприйняття суспільством, легкості тлумачення законів та ефективності роботи контролюючих органів. Він також комплексно оцінив переваги та недоліки податкових розривів, а також вказав на необхідність здійснення витрат на їх оцінювання та вигод від розрахунку даних показників.

Н. Геммен, Дж. Хасселдін (Gemmell N., Hasseldine J., 2012) досліджували методологічні засади оцінювання подат- 
кових розривів у США та Австралії при цьому дійшли висновків, що незважаючи на вдосконалені розрахунки та використання передових методологій отримані дані залишаються дискусійними. Питаннями оподаткування та реформування податкової системи займалися Н. Воррен, Ж. Макманус (Warren N., McManus J., 2007), які вбачали важливість використання розрахунків податкових розривів при удосконаленні оподаткування та всієї системи..

Серед вітчизняних вчених найбільше питаннями податкових розривів займалися А. Вдовиченко, А. Зубрицький (Вдовиченко А. М., Зубрицький А. І., 2013), які розглянули концепцію податкових розривів як індикатора есективності діяльності податкових адміністрацій, в свою чергу М. Фільо досліджував сутність податкових розривів (Фільо М. М., 2014).

Враховуючи важливість розрахунку та оцінки податкових розривів багато країн проводять їх розрахунок та оцінку але 356 держав лише 13 офріційно оприлюднюють дані (Тах administration, 2017). В Україні у 2018 р. було вперше проведено незалежну оцінку процесу адміністрування податків TADAT (the Tax Administration Diagnostic Assessment Tool), згідно з яким одним із основних недоліків у роботі ДФС є брак систематичного аналізу податкових розривів (Процеси адміністрування податків в Україні оцінили за методом TADAT, 2018).

Виходячи зі світового досвіду необхідно відмітити, що оцінка податкових розривів дозволяє правильно сформувати політику держави в напрямку їх зменшення та адміністрування податків. Україна на сьогодні робить тільки перші кроки в цьому напрямку, і якщо в секторі фізичних осіб відбуваються процеси декларування податків, прозоре оподаткування то в інших секторах, таких як великі підприємства та корпорації, робота щодо зменшення податкових розривів та збільшення сплати податків ще недостатня.

Корпоративний сектор економіки відіграє визначальну роль як у національній, так і в світовій економіці та суттєво впливає на міжнародні відносини. Основою даного сектору $є$ корпоративні інтегровані структури, ефективна діяльність яких залежить від розвитку декількох взаємопов'язаних процесів - корпоративних правовідносин, бухгалтерського обліку та оподаткування. Невизначеність, яка існує у правовому полі та в обліку і оподаткуванні з корпоративними правами, призводить до корпоративних конфліктів, тинізаціії економіки та великих податкових зривів. Як наслідок, це негативно впливає як на діяльність господарюючого суб'єкта, так і на національну економіку в цілому (Корпоративне право 2016: рекордні реформи, 2016 ).

Наукова дискусія на даний час переважно ведеться у площині розробки концепції корпоративних правовідносин. Разом з тим, питання облікового забезпечення корпоративних прав та їх оподаткування залишаються малодослідженими. Тому тема залишається дискусійною та актуальною на сьогодні.

Так у Господарському кодексі України статті 167 п. 1 міститься визначення корпоративного права: «корпоративні права - це права особи, частка якої визначається у статутному капіталі (майні) господарської організації, що включають правомочності на участь цієї особи в управління господарською організацією, отримання певної частки прибутку (дивідендів) даної організації та активів у разі ліквідації останньої відповідно до закону, а також інші правомочності, передбачені законом та статутними документами» (Господарський кодекс України, 2003). Аналогічне визначення корпоративного права наведено у п.п. 14.1.90 п. 14.1 статті 14 Податкового кодексу України (Податковий кодекс України, 2010).

Проте, якщо звернутися до наведених визначень у статті 167 Господарського кодексу України, то не зрозуміло між ким виникають корпоративні правовідносини. Господарським кодексом України визначено, що господарські організації - юридичні особи, створені відповідно до Цивільного кодексу України, державні, комунальні та інші підприємства, які здійснюють господарську діяльність та зареєстровані в установленому законом порядку.

У п. 3 статті 167 Господарського кодексу України надано роз'яснення, що під корпоративними відносинами маються на увазі відносини, що виникають, змінюються та припиняються щодо корпоративних прав. Стає очевидним, що вказані дефініції абсолютно не придатні для використання (Господарський кодекс України, 2003).

Відповідно статтею 116 Цивільного кодексу Украйни передбачається, як випливає зі статті 167 Господарського кодексу України, що учасники товариства мають право у порядку, встановленому установчим документом господарського товариства та законом: брати участь в управлінні, у розподілі прибутку і одержувати його частку (дивіденди), здійснювати відчуження часток у статутному (складеному) капіталі (Цивільний кодекс України, 2003).

Виходячи з вимог параграфу 4.25 Концептуальної основи фінансової звітності збільшення (зменшення) власного капіталу, пов'язане з внесками або виплатами учасникам, при визначенні доходів та витрат діяльності не враховується (Концептуальна основа фінансової звітності: IASB, 2010). Це підтверджує той факт, що операції з обміну корпоративних прав на внески учасників не впливають на доходи чи витрати господарського товариства.

У статті 14 п. 14.1 Податкового кодексу України наведено визначення понять, які стосуються безпосередньо оподаткування корпоративного права (корпоративних відносин), зокрема:

- відчуження майна - будь-які дії платника податків,унаслідок вчинення яких такий платник податків у порядку, передбаченому законом, втрачає право власності на майно, що належить такому платнику податків, або право користування (п.п. 14.1.31);

- дохід з джерелом походження з України - будь-який дохід, отриманий резидентами або нерезидентами, у тому числі від будь-яких видів діяльності на території України, доходи у вигляді:

а) процентів, дивідендів, роялті та будь-яких інших пасивних (інвестиційних) доходів, сплачених резидентами України;

б) доходів від продажу рухомого та нерухомого майна, доходів від відчуження корпоративних прав, цінних паперів, у тому числі акцій українських емітентів (п.п. 14.1.54);

- інвестиції - господарські операції, які передбачають придбання основних засобів, нематеріальних активів, корпоративних прав та/або цінних паперів в обмін на кошти або майно. Інвестиції поділяються на: 
б) фінансові інвестиції - господарські операції, що передбачають придбання корпоративних прав, цінних паперів, деривативів та/або інших фонансових інструментів, які поділяються на: прямі інвестиції - господарські операції, що передбачають внесення коштів або майна в обмін на корпоративні права, емітовані юридичною особою при їх розміщенні такою особою; портфельні інвестиції - господарські операції, що передбачають купівлю цінних паперів, деривативів та інших фінансових активів за кошти на фондовому або біржовому товарному ринку (п.п. 14.1.81);

- пов'язані особи - юридична та/або фізична особи, відносини між якими можуть впливати на умови або економічні результати їх діяльності чи діяльності осіб, яких вони представляють, з урахуванням таких критеріїв:

а) для юридичних осіб: одна юридична особа безпосередньо та/або опосередковано (через пов'язаних осіб) володіє корпоративними правами іншої юридичної особи у розмірі 20 і більше відсотків; одна і та сама особа юридична або фізична особа безпосередньо та/або опосередковано володіє корпоративними правами у кожній такій юридичній особі у розмірі 20 і більше відсотків;

б) для фізичної особи та юридичної особи: фізична особа безпосередньо та/або опосередковано (через пов'язаних осіб) володіє корпоративними правами юридичної особи у розмірі 20 і більше відсотків (п.п. 14.1.159) (Податковий кодекс України, 2010).

Розділом IV статтею 162 ПКУ визначено, платником податку є фізична особа - резидент, яка отримує доходи як 3 джерела їх походження в Україні, так і іноземні доходи; а також фізична особа - нерезидент, яка отримує доходи з джерела їх походження в Україні. Базою оподаткування є загальний оподатковуваний дохід, з урахуванням особливостей. До загального місячного (річного) оподатковуваного доходу платника податку включається інвестиційний прибуток від проведення платником податку операцій з цінними паперами, деривативами та корпоративними правами, випущеними в інших, ніж цінні папери, формах.

Ставка податку на пасивні доходи до бази оподаткування встановлюється у таких розмірах: 5 відсотків - для доходів у вигляді дивідендів по акціях та корпоративних правах, нарахованих резидентами - платниками податку на прибуток підприємств; у половинному розмірі ставки, встановленої п.
167.1 статті 167, (9 відсотків) - для доходів у вигляді дивідендів по акціях та корпоративних правах, нарахованих нерезидентами та суб'єктами господарювання, які не є платниками податку на прибуток підприємств (Податковий кодекс України, 2010).

Статтею 196 п. 196.1 п.п. 196.1.6 визначено, що не $є$ об'єктом оподаткування податком на додану вартість (ПДВ), виплата дивідендів у грошовій формі або у вигляді цінних паперів, які здійснюються емітентом. ПДВ також не нараховується при поверненні майна учаснику, якщо до статутного капіталу вносили не саме майно, а право на користування ним (Податковий кодекс України, 2010).

Перехідними положеннями Податкового кодексу України з 2014 року введено новий податок - військовий збір. Об'єктом оподаткування визначено виплати пов'язані з трудовими та цивільно-правовими відносинами зі ставкою 1,5 відсотки у всіх випадках. 32015 року база оподаткування значно розширена, зокрема до місячного (річного) оподаткованого доходу включені доходи від операцій з майном, пасивні доходи (дивіденди) тощо.

Проведені дослідження законодавства України дозволяють стверджувати, що воно не відповідає сучасним вимогам та законодавству ЄС. Тому що у статті 15 Договору про Європейський Союз закріплено, що важливою умовою для зміцнення економічних зв'язків між Україною та Співтовариством є зближення існуючого та майбутнього законодавства України з законодавством Співтовариства (Договір про Європейський Союз, 2007). Сьогодні Україна постійно проводить роботу з достосування свого законодавства до вимог ЄС. Тому ми вважаємо, що врегулювання невідповідностей приведе до прозорості в сплаті податків, детінізації української економіки та налагодженню тісних та взаємовигідних стосунків з країнами Європейського Союзу.

Висновки. Підсумовуючи проведене дослідження необхідно зробити висновок про те, що аналіз міжнародних практик оцінювання податкових розривів в економіці та законодавства України щодо сфери корпоративних відносин показує, що адаптація законодавства та розглянутих методик до особливостей сучасної податкової системи України приведе до детінізації економіки та збільшення податкових надходжень. Подальші розвідки будуть направлені на покращення методології обрахунків податкових розривів в економіці країни.

\section{Список використаної літератури:}

1. Civil Code of Ukraine: Law of Ukraine of January 16, 2003, No. 435-IV. Available at: http://zakon5.rada.gov.ua/laws/show/435-15/page4. (Accessed 05/10/2019).

2. Conceptual Basis for Financial Reporting: IASB. Standard dated 01.09.2010, IASB. Available at: http://zakon3.rada.gov.ua/laws/show/929_009/page2. (Accessed 05/10/2019).

3. Corporate Law 2016: Record-breaking Reforms (2016). Legal newspaper. No. 45 (543). P. 30-31.

4. Economic Code of Ukraine: Law of Ukraine of January 16, 2003, No. 436-IV. Available at: http://zakon2.rada.gov.ua/laws/show/436-15/page7. (Accessed 05/10/2019).

5. Filho M.M. (2014) Tax Losses and Tax Gaps: Identification Opportunities. Bulletin of the Odessa I.I. Mechnikov National University. Volume 19. Issues 5-6. P. 115-120.

6. Gemmell N., Hasseldine J. (2012). The tax gap: a methodological review. Advances in Taxation. P.203-231.

7. Hamilton S. (2015) Regulatory compliance, cases election and coverage - calculating compliance gaps. Journal of Tax Research. Vol. 13. № 2, P. 616-673.

8. Limited liability and subsidiary companies. Law of Ukraine dated 06.02.2018 № 2275-VIII. Available at: http://www.golos.com.ua/article/300823. (Accessed 05/10/2019).

9. Schwabiy, KI, Zadorozhnya, LA (2018) International practice of estimating the tax gap from personal income tax. Scientific notes of the Ostroh Academy National University. The Economy Series (9 (37)). P. 174-178.

Вісник Сумського національного аграрного університету 
10. Tax administration 2017: Comparative Information on OECD and Other Advanced and Emerging Economies. OECD Publishing. 2017. $380 \mathrm{p}$.

11. Tax administration processes in Ukraine have been evaluated using the TADAT method. Available at: https://goo.gl/kiEvhK (Accessed 10/05/2019).

12. Tax Code of Ukraine: Law of Ukraine dated 02.12.2010 № 2755-Vl. Available at: http://zakon2.rada.gov.ua/laws/show/2755-17/page3. (Accessed 05/10/2019).

13. Treaty on European Union. International Document of 07.02.1992 Available at: http://zakon0.rada.gov.ua/laws/show/994_029. (Accessed 05/10/2019).

14. Vdovichenko AM, Zubritsky Al (2013) Tax Gaps: Theory and Possibilities of Implementation in Ukraine. Economy and the state. No. 8. P. 17-21.

15. Warren N., McManus J. (2007). The Impact of Tax Gap on Future Tax Reforms. The Australian Economic Review. Vol. 40. № 2. P.200-207.

Olena Slavkova, Dr, Professor, Sumy National Agrarian University (Sumy, Ukraine)

Mykola Hordiienko, PhD, Professor, Sumy National Agrarian University (Sumy, Ukraine)

Corporate legal relations and tax gaps: the theoretical approach

The article analyzes the international practice of using tax gap assessments, particularly in Australia, Canada, the United Kingdom, the United States of America, Sweden and others. It has been found that this indicator is considered as a derivative of the level of tax culture of enterprises, organizations and citizens of the country and is characterized by a low level of tax gap.

It has been established that the main basic component of determining the size of the tax gap in developed countries is the universal income declaration and financial disclosure. It is determined that corporate rights are subject to taxation. The analysis of the Ukrainian legislation is carried out and it is concluded that the current legislation of Ukraine does not meet the modern requirements and the legislation of the EU. Article 15 of the Treaty on European Union stipulates that an important condition for strengthening economic ties between Ukraine and the UE is the approximation of the existing and future legislation of Ukraine to the legislation of the EU. Ukraine will take measures to ensure that its legislation is gradually brought into harmonization with the EU laws. Such legislation also includes legislation governing the recognition, assessment, accounting and taxation of corporate rights.

It is concluded that at the state level it is necessary to implement an effective financial disclosure and auditing system to reduce tax gaps in the corporate rights sector.

Key words: taxation, tax gap, corporate rights, corporate legal relations.

Дата надходження до редакції: 15.10.2019 р. 